\title{
The Bifurcation of Politics: Two Englands
}

\author{
Forthcoming in The Political Quarterly
}

Will Jennings, University of Southampton

Gerry Stoker, University of Canberra/Southampton

Acknowledgements: Earlier versions of this paper benefitted from comments provided through presentations at the Australian Political Studies Association Conference, Canberra, September 2015. The authors would like to thank the UK's Economic and Social Research Council for funding of the project 'Popular Understandings of Politics' (ref. ES/L007185/1). Thanks also to Ian Warren for advice on the Mosaic geodemographic classification of parliamentary constituencies. 


\begin{abstract}
A dynamic of global economic development means that many countries are experiencing uneven development and their citizens are increasingly split between those who can access high skill jobs and those that cannot. As a result some citizens are living in cosmopolitan areas of growth and others in backwater areas of decline. There is emerging out of these processes two versions of England. In cosmopolitan areas we find an England that is global in outlook, liberal and more plural in its sense of identity. In provincial backwaters we find an England that is inward looking, relatively illiberal, negative about the EU and immigration, nostalgic and more English in its identity. This bifurcation of England is already having political effects reflected in the outcome of 2015 General Election. It will further reconfigure politics over the next two decades, creating diverse political citizens and a complex array of challenges and dilemmas for governments, political parties, campaigners and political organisers.
\end{abstract}

Keywords: globalisation, economic change, anti-politics, class dealignment, locality 
There is in England a growing divide in the political outlook of citizens in different places. Where you live can shape how you experience the world and structure your political perspective. Some citizens are living in cosmopolitan areas of growth and others in provincial backwaters experiencing decline. This bifurcation of experience and circumstances is already impacting political outlooks and behaviour. With the decline of traditional class cleavages and associated political loyalties, place-based experiences provide a new dynamic that is pulling cosmopolitan and backwater locations further apart and increasingly framing the political choices of citizens.

There are emerging out of these processes two versions of England. Geographical differences have not only become sharper but have developed a strong cultural dimension. In cosmopolitan areas we find an England that is global in outlook, relatively positive about the EU, pro-immigration, comfortable with more rights and respect for women, ethnic communities and gays and lesbians and generally future-oriented. In backwaters we observe instead an England that is inward looking, relatively negative about the EU and immigration, worried by the emergence of new rights for "minorities" and prone to embracing nostalgia.

This bifurcation of England is already having political effects that will further reconfigure politics over the next two decades, creating diverse political citizens and a complex array of challenges and dilemmas for governments, political parties, campaigners and political organisers. Post-war differences between places were reflected in more solid class blocs and based to a large degree on material inequality. In this context political mobilisation was easier to achieve and a political offer of economic growth for all could be made to "let all boats rise". But the cosmopolitan/backwater schism of the twenty-first century presents different and more problematic challenges for political elites. First, as we will show, it exists in the context of intense negativity towards mainstream politics, an outlook shared in both growing and declining areas. Second, cultural differences are less easily reconciled or subject to political compromise. Third, changes in the economics of different places are reinforcing and sustaining differences, making it hard to operate with one political platform in the two "Englands".

Our evidence of divergent political attitudes and practices from citizens is provided by the British Election Study (BES); supplemented on one question by material from a survey specifically commissioned by the authors. We compare attitudes cosmopolitan and backwater constituencies in 2015 and show some stark differences. Data from 1997 is used to explore 
whether and how the differences between cosmopolitan and backwater locations have changed over time. We start with an account of how we constructed our research before presenting the key findings and then discuss differences (and some similarities) in the outlooks of the two types of area and how these have changed over time. We close by discussing the implications of our findings for political elites and emerging forms of political citizenship.

\section{Approaching the two Englands}

There is a pattern of change that can be seen in contemporary democracies between cities and regions that are booming and creating high skill, high paid jobs and those that are declining and increasingly dominated by low skill, low paid jobs. Jeremy Cliffe argues economic dynamism is located around cosmopolitan cities with London, Cambridge and dynamic cities such as Manchester at the core. ${ }^{i}$ However alongside these kinds of cosmopolitan areas are provincial backwaters - such as Clacton - that show few signs of economic dynamism. ${ }^{\mathrm{ii}}$ Global economic change is driving uneven development and dividing areas between those where residents can access high skill jobs and those where they cannot.

The idea that political outlooks might differ as a result of diverse geographical experiences is relatively uncontroversial. Spatial clustering of political practices and perspectives could be expected for a number of reasons. The most important factors are probably contextual where through shared experiences and regular interactions people come to see the world through a similar lens. It might also be that people self-select into areas they believe share their outlook. The evidence on this point is difficult to assemble. Studies suggest that self-selection is not made so much on political grounds but rather that processes work through the socioeconomic standing, employment and parental status of individuals, ${ }^{i i i}$ that is they self-select but on non-political grounds. In short, context and self-selection work together to produce location effects. The emerging patterns of these effects in English politics is the focus of attention here.

In order to explore differences between the politics of cosmopolitan and backwater areas in England we started with the constituencies of Clacton and Cambridge as our benchmarks. These are, respectively, exemplars of backwater and cosmopolitan locations. We draw on survey data from waves of the 2014-15 British Election Study (BES) Internet Panel and the 2015 BES face-to-face post-election survey. Each wave of the BES Internet Panel consists of 
a sample size of around 30,000 respondents and the face-to-face survey consists of around 3,000 . We are able to identify respondents residing in two sets of fifty constituencies resembling the geodemographic profiles of Clacton and Cambridge (consisting of around 5,000 respondents of the sample for the Internet Panel and 500 respondents for the face-toface survey). We first used the Mosaic geodemographic segmentation classifications to identify the proportion of the population resident in each of the Clacton and Cambridge constituencies classified under each Mosaic type. We then refined these profiles based on the theoretical trajectories of cosmopolitan and backwater destinations to develop general types, and calculated the top-50 scoring English constituencies across those Mosaic categories (see supplementary materials, Tables S1 and S2). This inductive approach means our backwaters tend to be drawn from aging coastal towns, with a history of light rather than heavy industry, sometimes characterised by the decaying vestiges of Victorian seaside resorts. As a result our sample constitutes a particular expression of economic decline, and does not tend to include declining towns in Northern England which are being shaped by the ongoing processes of deindustrialisation. The nature of politics in those areas of economic decline may differ from the two Englands we identify here. We use data from the 1997 BES post-election survey to compare whether and how the differences between cosmopolitan and backwater locations have narrowed or widened over time.

\section{Dimensions of difference: attitudes, identity and disaffection}

Differences in the demographics and social and economic circumstances of the populations of cosmopolitan and backwater areas would suggest that their residents might display substantial disparities in their social and political outlook. ${ }^{\text {iv }}$ The survey data from 2014-15, presented in the columns on the right-hand side of Table 1, confirms that expectation, with the population of backwater areas being significantly more negative about immigration and Europe - and being significantly more negative than the average voter too. Cosmopolitan citizens on average are more socially liberal and are more open to change, immigration and global demands. ${ }^{v}$ Citizens in backwater areas are more socially conservative, and also more likely to identify as English or at least as equally English and British (76\% compared to $51 \%) .{ }^{\text {vi }}$ Cosmopolitan and backwater areas look like two "Englands"; the former confident and outward-looking and the latter anxious and inward-looking.

Comparing attitudes in these locations with equivalent measures from 1997, presented in the left-hand columns of Table 1, provides important and novel insights. Strikingly, the gap in 
attitudes on immigration has increased (from +9 in an equivalent question in the 1997 BES to +14 and +16 for questions in the 2015 BES). The shift in opinion on Europe is such that there has been a reversal, where backwater areas had previously lagged behind on support for leaving the EU in 1997 (-9), in contrast to their strong euro-scepticism of today (+15). These findings point to a fundamental shift in the politics of these areas.

Perceptions that equal opportunities for ethnic minorities and gays and lesbians have gone "too far" also differ significantly across the groups, though opposition to gender equality is similarly uncommon in both places. On equalities for minorities there has been a significant polarization of attitudes. In 1997, respondents in backwater settings were marginally less likely to agree that equal opportunities for ethnic minorities had gone too far (-2). By 2015, there was a large gap between the two populations in the other direction $(+13)$. Interestingly, we see no equivalent shift in attitudes on gays and lesbians (where the gap has remained fairly stable between the two points and time), and a narrowing of differences on gender equality (though small in magnitude). Lastly, one of the characterisations of backwater "left behind" settings points to nostalgia about a bygone era. Whereas the 1997 BES saw greater support for customs and tradition in cosmopolitan settings (-10), a 2014 Populus survey found much higher support for "turning the clock back to the way Britain was 20-30 years ago" in backwater areas (+14). While not directly comparable, this does suggest a substantial shift in the nostalgic politics of these sorts of area.

We also see a growing divide in terms of expressions of identity in these areas. In general there has been a shift towards Englishness as distinct from Britishness, with the percentage of respondents saying that they are English not British rising from $7 \%$ to $13 \%$. The gap between cosmopolitan and backwater settings has risen slightly from +6 to +8 , with cosmopolitans being significantly less likely to indicate Englishness as their single national identity. There has been a significant rise in the number of cosmopolitan residents saying they have no national identity (11\% compared to $1 \%$ in 1997, coinciding with a fall in the proportion of 'other' from $18 \%$ to $4 \%$ ), which contrasts with the relative absence of this group in backwater settings $(0 \%)$. The gap between those that describe themselves as "White British" between 1997 and 2015 has increased substantially, reflecting the changing demographics of England. Across the country there has been a decline, but in backwater locations $96 \%$ of the population are White British compared with 70\% in cosmopolitan areas, a 15\% decline in the latter since 1997. In summary, the growing polarization of attitudes between the two Englands has been 
accompanied by nuanced yet important changes in expressions of identity. Backwater areas have become more ingrained in a White British and English identity and cosmopolitan areas have seen an expansion and greater pluralism in people's expressed identity. 
Table 1: Political attitudes and identity in cosmopolitan and backwater settings in England

\begin{tabular}{|c|c|c|c|c|c|c|}
\hline & & 1997 & & & $014-1$ & \\
\hline & $\begin{array}{l}\text { Cosmo- } \\
\text { politan }\end{array}$ & All & $\begin{array}{l}\text { Back- } \\
\text { water }\end{array}$ & $\begin{array}{l}\text { Cosmo- } \\
\text { politan }\end{array}$ & All & $\begin{array}{l}\text { Back- } \\
\text { water }\end{array}$ \\
\hline Immigration/Europe & & & & & & \\
\hline Immigration bad for the economy $^{\dagger}$ & - & & - & 29 & 42 & 45 \\
\hline Immigration undermines cultural life ${ }^{\dagger}$ & - & & - & 38 & 48 & 52 \\
\hline Black and Asian immigration bad for Britain & 27 & 37 & 36 & - & - & - \\
\hline Britain should withdraw from EC/Would vote to leave the EU & 31 & 31 & 22 & 35 & 44 & 50 \\
\hline Dissatisfied with EU democracy & - & - & - & 76 & 79 & 82 \\
\hline Social Change & & & & & & \\
\hline Equal opportunities for minorities gone too far ${ }^{\wedge}$ & 22 & 26 & 20 & 34 & 43 & 47 \\
\hline Equal opportunities for women gone too far ${ }^{\wedge}$ & 12 & 9 & 8 & 13 & 14 & 13 \\
\hline Equal opportunities for gays and lesbians gone too far ${ }^{\wedge}$ & 29 & 39 & 42 & 25 & 31 & 36 \\
\hline Better to keep customs and tradition than to adapt/blend & 29 & 20 & 19 & - & - & - \\
\hline Would turn clock back to way Britain was $20-30$ years ago ${ }^{*}$ & - & - & - & 39 & 46 & 53 \\
\hline Identity & & & & & & \\
\hline English not British ${ }^{+}$ & 3 & 7 & 9 & 7 & 13 & 15 \\
\hline More English than British ${ }^{+}$ & 13 & 17 & 17 & 8 & 10 & 9 \\
\hline Equally English and British ${ }^{+}$ & 34 & 45 & 45 & 36 & 48 & 52 \\
\hline More British than English ${ }^{+}$ & 13 & 14 & 16 & 13 & 10 & 10 \\
\hline British $^{+}$ & 16 & 9 & 7 & 19 & 10 & 10 \\
\hline None $^{+}$ & 1 & 1 & 1 & 11 & 3 & 0 \\
\hline Other $^{+}$ & 18 & 5 & 6 & 4 & 4 & 3 \\
\hline Ethnicity & & & & & & \\
\hline Race/ethnic group or background (self-rated): White British ${ }^{\wedge \dagger \#}$ & 85 & 93 & 98 & 70 & 88 & 96 \\
\hline
\end{tabular}

Note: all data for 1997 from the British Election Study face-to-face post-election survey, 1997.

${ }^{\wedge}$ British Election Study Internet Panel, Wave 1, 2014.

${ }^{\dagger}$ British Election Study Internet Panel, Wave 4, 2015.

\# British Election Study Internet Panel, Wave 6, 2015.

${ }^{+}$British Election Study face-to-face post-election survey, 2015

* Populus, Survey for Universities of Southampton and Canberra, 2014. 


\section{Dimensions of citizenship: political engagement anti-politics}

We were interested not only in attitudes in cosmopolitan and backwater locations but also in differences in modes of political engagement. These are shown in Table 2. Interestingly, there are fewer differences between backwater settings and the average English constituency, suggesting it is more cosmopolitan places which differ in terms of participation, ${ }^{\text {vii }}$ though turnout is higher in backwater locations. Overall, the pattern of participation beyond voting matches that long found in audits of political engagement, ${ }^{\text {viii }}$ where low cost activities such as signing a petition or boycotting a good/service figure strongly.

Table 2: Modes of political participation

Turnout $^{+}$

$\begin{aligned} & \text { Cosmo- } \\ & \text { politan }\end{aligned}$ All water
wate

Actions undertaken in last 12 months, offline $e^{\#}$

Contacted politician, government, local government official

Signed petition (not on Internet)

Done work on behalf of political party or action group

99

Donated to a political party, organization or cause

8

$6 \quad 5$

Taken part in a demonstration

Boycotted/purchased products for political/ethical reasons

Gone on strike or taken industrial action

$12 \quad 8 \quad 8$

422

$19 \quad 14 \quad 13$

Actions undertaken in last 12 months, online

Signed petition on Internet

During last 4 weeks posted or shared any political content online ${ }^{\dagger}$

Shared political content on Facebook

$15 \quad 13 \quad 11$

Shared political content on Twitter

Shared political content on e-mail

Shared political content via instant messaging

During last seven days, time spent per day following news/politics/current affairs on the Internet (1 hour or more)

${ }^{\dagger}$ British Election Study Internet Panel, Wave 5, 2015.

\# British Election Study Internet Panel, Wave 6, 2015.

${ }^{+}$British Election Study face-to-face post-election survey, 2015

There are some differences in levels of engagement in political activity that takes place online. In cosmopolitan areas, $41 \%$ of respondents had signed a petition on the Internet within the past 12 months, compared to $36 \%$ for those from backwater areas. Similarly, 
cosmopolitans were more likely to have shared political content on Facebook or Twitter (as measured in the pre-election survey wave), and spent more time per day following news, politics or current affairs on the Internet for an hour or more compared to their counterparts in backwater locales. ${ }^{\text {ix }}$ Our findings therefore suggest that the cosmopolitan-backwater schism extends to a degree to political engagement as well as social attitudes, and applies to both traditional and digital modes of political action.

The final issue we tested attitudes on was on how our political system is judged. While it has been argued that backwater "left behind" localities exhibit distrust of mainstream politics and openness to various forms of populist challenge ${ }^{\mathrm{x}}$, we do not see distinctive expressions of anti-political sentiment in cosmopolitan or backwater settings. Both sets of populations look remarkably similar to the average voter across England. This finding leaves the question of what might be driving the negativity of cosmopolitan residents. The answer is more likely to lie in the processes of politics rather than its failure to deliver. The evidence in Table 3 suggests it is perceptions of politicians and the conduct of politics that is the problem.

Table 3: Attitudes towards politics and politicians

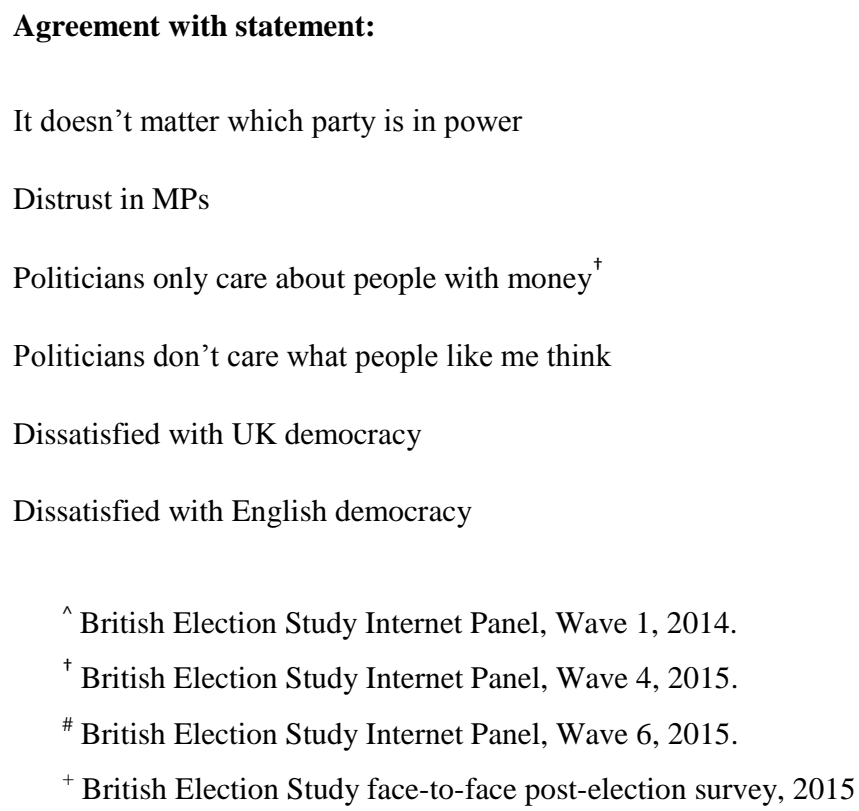

\section{Exploring the results: implications for politics}

Where you live matters and our evidence indicates that two Englands are emerging: one cosmopolitan and one backwater. Because the BES offers us a nationally representative sample, we can show that, even after demographic and socio-economic factors are accounted 
for, it appears that those living in backwater and cosmopolitan areas hold distinctive views and are on different political trajectories. In this section of the article we begin to explore the implications of this bifurcation of politics.

\section{Challenges for national elites}

The emergence of the two Englands brings into play a new political dynamic. In majoritarian systems such as the UK's, the challenge for party elites is to build an electoral coalition that straddles the divides created by the bifurcation of politics. Table 4 suggests, on the basis of the results of the 2015 General Election, that the Conservative Party in England has proved better at this than Labour. The Conservatives appear to be both more adept and more pragmatic in their willingness to provide targeted and focused appeals to a wider variety of constituencies. They have a strong foothold in both cosmopolitan and backwater areas (receiving $34 \%$ of the vote in the former), and notably outperform Labour in attracting votes in backwater constituencies by a ratio of over $3: 1$. In contrast, Labour is ahead in cosmopolitan areas. The pattern of support for other parties matches expectations. UKIP is twice as strong in backwater settings. The Greens are stronger in cosmopolitan locations. The Liberal Democrats fared evenly (badly) between the two.

Future electoral trajectories will to a degree be framed by how effective parties are at dealing with the cosmopolitan/backwater divide. The dilemmas facing political leaders will become considerably more acute. So, for example, right-of-centre parties such as the Conservatives will need to make sure they reach out to ethnic minorities and do not pander too much to the fears about immigration expressed in backwater areas, although they will still need to address some of the policy issues raised by the control of migrant numbers and by the impact of migration. The issue of Europe looms large for their prospects too, with the fallout from the EU referendum - whatever the result - being difficult to manage as the prevailing mood in cosmopolitan and backwater constituencies appears to be heading in opposite directions, leaving one group likely to be disappointed and looking for someone to blame. All parties will need to take on board the emerging economic strength and growth of cosmopolitan areas and pitch themselves in a way that recognises the liberal, progressive outlook of many citizens in those areas.

On the left, Labour's problem is that it is struggling in backwater areas and is by no means dominant in cosmopolitan areas. Moreover the public image of its leadership - reinforced by 
the election of Jeremy Corbyn as leader - suggests a cosmopolitan bias in outlook and appeal. Too many voters see Labour as thinking global and neglecting more "mundane" English concerns. The party elite and its members (found to be disproportionately "high-status city dwellers" ${ }^{\text {xi }}$ ) share the values of cosmopolitan England and have less in common with the politics of backwater locations. Labour is consequently struggling to develop a policy platform that reflects the concerns of backwater areas, instead focusing on issues - such as Trident - that are out of step with public opinion in backwater locations. It is possible that an anti-austerity message could gain traction with voters in backwater areas but Labour's cultural cosmopolitanism may make it difficult for that message to be heard. Equally it is possible that a compromise over immigration policy could be designed to appeal in both cosmopolitan and backwater areas but there may be a barrier created by the cosmopolitan outlook of the leadership - that equates expressions of concern about immigration with racism - that can block pragmatic policy positioning.

Table 4: Vote share in the 2015 general election, English constituencies

\section{Reported vote ${ }^{+}$}

Conservative

Labour

Liberal Democrat

UKIP

Green

${ }^{+}$British Election Study face-to-face post-election survey, 2015

\section{Cosmopolitan}

10

6

6
All

34

7

11

4
Backwater

A further challenge is to govern in a way that does not lead to rapid decline in popular support because designing policies to suit both cosmopolitan and backwater areas is a difficult and precarious business. Policy measures might be targeted at individuals (for example increased public investment in education and training in backwater areas) or be place-based (for example giving priority to the environmental quality of life in areas left behind by the trajectory of urban development). Neither of these measures is easy to deliver. People-focused policies may be difficult to resource both in terms of the finances required and in terms of getting the human resources (the skilled or professional support staff) in the right locations. Place-oriented strategies that mean giving up on growth and accepting decline 
are not easy policy options to sell. The challenges facing policy-makers in backwater locations are considerable. Simplistic policy options of attracting new industries or sectors can be little more than wishful thinking. Practical constraints such as a shrinking fiscal base, unused or empty properties and a lack of relevant skills in the population loom large.

The Conservatives' preferred solution would appear to be to push the challenges away from central government towards local government and new forms of regional governance. A range of "radical" devolution plans ${ }^{\mathrm{xii}}$ for England which involve generic new responsibilities and fiscal autonomy for local government, new devolved arrangements with the NHS and bespoke regional deals for particular locations is unfolding. But there are reasons for questioning some of these developments. One fear is that what is on offer is greater local responsibility without the effective power or resources to develop effective solutions. The Treasury appears to grant autonomy to control and raise local taxes but then builds in assumptions about efficiency savings and those tax funds into big cuts in centrally provided revenue support. Moreover it appears that the desire to have nationally-led policy initiatives on display has hardly disappeared in areas such as housing and education. The position is at best a rather muddled and at worst a faux devolution programme. On the other hand in this unpredictable new world what may also emerge is a more effective voice for declining areas - especially through the proposed election of city region mayors - making the management of politics more challenging for Westminster and Whitehall.

For cosmopolitan areas the policy dilemmas are no less acute. Managing housing supply, ensuring transport links and maintaining the cultural and environmental attractions of the location can be demanding. There are also likely to be a variety of "hot button" issues in these areas around development and infrastructure plans that will be difficult to manage both in terms of central-local government and government-citizens relations. For instance, targets for house-building in cosmopolitan locations may be controversial. The row over expansion of Heathrow - and repeated political deferral of the final decision - is another example. Again for growth-oriented cosmopolitan areas the most likely governance prescription is a greater degree of devolved power to these areas so that civic leaders and citizen organisations can adapt with flexible strategies to their growth environments. But there are still likely to be dilemmas in terms of the degree of autonomy allowed and the redistribution of the wealth created in growing areas to those areas "left behind". The issue of distribution of public investment is likely to become more severe. Those areas that generate growth need 
investment but so do those left behind. The tensions over these issues are reflected in reactions to the latest local government financial settlement.

Political elites may argue they can adapt and survive as they have in the past to new political demands. The policy agenda can be twisted to meet diverse demands, they might argue. But there are (at least) three reasons for doubting that the bifurcation of politics between backwater and cosmopolitan locations will involve only a modest shift in the behaviour and outlook of political elites.

The first is that the divide between backwater and cosmopolitan areas is unlikely to be resolved by backwater areas catching up, given the sustained and powerful nature of the global forces that are driving change. There is a material base to the concerns of different types of citizens about the direction of politics that is likely to be sustained for a number of decades, and may even accelerate. Winners and losers are being created by the dynamics of emerging backwater and cosmopolitan areas and smarter, better politics by mainstream parties or other political actors cannot necessarily address that fundamental divide.

A second factor, as already demonstrated in Table 3, is that neither declining nor growing areas appear to have citizens who particularly trust politics. Voters are therefore alert to political games and view politicians from all sides with disdain. They are especially on the lookout for authenticity in politics. You cannot be against immigration and then expect those who live in economies that thrive on it to rush to vote for you. Equally for a mainstream party to trim on issues such as immigration "is a losing strategy as the votes that are potentially won by shifting closer to the populist position are balanced by those lost from more moderate voters, alienated by a move from the centre". xiii In addition anti-political sentiment makes mainstream parties more vulnerable to sustained populist challenge. The evidence we have thus far is that populists, whether sharing power or effectively excluded from office, retain their radical and distinctive policy positions. Although larger mainstream parties can steal some of their policy positions they cannot move too far for fear of alienating other voters. ${ }^{\text {xiv }}$ Once a populist, always a populist; there is no point moving to the middle ground and if you do someone will take your place. Populism has a material base and although it may change its institutional expression it is unlikely to disappear as long as the material base remains. Some party or campaign group will always follow the political logic of attempting to represent themselves as flag-bearers for those concerns. 
A third reason for stressing the sustained challenge of new cleavages is that the increasingly fragmented and volatile issue agenda of national politics is driven in part by dynamics that are accentuating the divide between cosmopolitan and backwater areas, leaving policymakers with an increasing number of issues on which there is no middle ground. For example, higher levels of education are associated with a more diverse and unstable public agenda, ${ }^{\mathrm{xv}}$ while the rise of post-materialist issues like the environment and niche issues such as immigration have displaced the traditional dominance of the economy, defence and foreign affairs as the focus of public concern. Yet the capacity of government to deal with issues has not increased at the same pace, putting pressure on the political agenda leading to more rapid turnover and greater volatility. Moreover the cultural aspect to these divisions makes for a different set of political dilemmas compared to the past splits based more directly on material differences. The divide between cosmopolitan and backwater locations is such that political appeals based on growth and material gain for all are not only implausible (given the global economic logic) but also limited, as they do not deal the cultural divides which separate voters in the two locations. You cannot authentically be both liberal and non-liberal on social rights, both for and against immigration, or keen on England as part of new global cosmopolitan world and at the same time appeal to fearful little Englanders.

\section{New political citizens?}

Changing patterns of location could be a source of new political practices but the choices open to citizens are still contingent on their values and preferences. Neither backwater areas nor cosmopolitan areas will necessarily produce a single type of new political outlook and practice among its residents, even among those who are exemplars of the differences between the areas. The picture is likely to be complex but it is possible to characterise the emerging trends. In general it is easier to identify the political trajectory of those in backwater rather than cosmopolitan locations.

It has been shown ${ }^{\mathrm{xvi}}$ that in Britain there are emerging two types of negativity towards politics. The first is the "disaffected" democrat who has low trust in political elites but is keen to participate more, argues for a new type of politics and is interested in political engagement but on their own terms and using a non-traditional repertoire. For them the issue is the need for democratic transition. The second group - who can be labelled "stealth" populists - also displays considerable political negativity towards the Establishment and political elite but is 
more traditional in its political repertoire and commitment to political institutions. The issue for this group is less the need for new democratic mechanisms and more for existing political institutions to be better led. The call from this group is to change the nature of modern elites that are seen as out-of-touch, too liberal and unable or unwilling to deal with its key issues of concern.

Residents of backwater locations may well feel alienated by mainstream politics and political elites and are prone to a stealth populist outlook of politics that has at its heart a sense that the people have been left behind by a political class that is running the system for its own benefit not that of the average citizen. ${ }^{\text {xii }}$ The emergence of left- and right-wing populism is a feature of the landscape in many contemporary democracies and our evidence would indicate that its strongest home is going to be in backwater locations that are fertile for the growth and spread of political disaffection. The most obvious expression is the emergence of UKIP as a political force providing a platform for right-wing populism. ${ }^{\text {xiii }}$ It is possible that changes in the focus and orientation of the Labour Party under Jeremy Corbyn would provide scope for left-wing populism, which has been absent largely in Britain but has surfaced in a number of southern European countries. ${ }^{\text {xix }}$

Some cosmopolitan citizens might be put into the camp of emerging disaffected democrats but we would be keen to emphasise the heterogeneity of cosmopolitan citizens. Some may be looking for parties to provide a radical alternative to mainstream assumptions about society, economy and the environment. They may want back a left-leaning Labour Party or look to the Green Party instead. Others may mix social liberalism with a preference for mainstream economic management and find themselves backers of centre-oriented parties of right or left. Moreover we are uncertain about claims of a new type of politics emerging from these cosmopolitan areas. Some residents of cosmopolitan areas may become standard-bearers for "oppositionalist" politics using social media and short-lived political movements to express their concerns on a range of issues that matter to them. These political actors may be unwilling to tie themselves to any political party or, if they do, may treat the party as part of a movement rather than displaying great institutional loyalty (a feature of some of the new or returning members of the Labour Party under Corbyn).

What our evidence suggests, at least in terms of the repertoire of participation, is that many citizens in both cosmopolitan and backwater locations will be relatively inactive when it comes to political actions beyond voting. That is not to say that they will be apathetic or non- 
participants. Following the work of Ekman and Amna it becomes possible to look beyond manifest participation and non-participation towards latent or "standby" participation where citizens are ready to engage even if not regularly doing so. ${ }^{\mathrm{xx}}$ They practice a range of activities that might be called pre-political but could become political. They might express interest in politics and claim some knowledge of it. They may be active in their community in non-political organisations and will follow current affairs and talk about issues with family and friends or on social media. Will standby politics mixed with manifest participation be more prevalent still as the cycle of dipping in and out of politics becomes easier and more effective in the world of social media? The higher levels of engagement using online tools in cosmopolitan areas tend to reflect demographic differences (and use of technology) rather than a more substantial change of political style (at least as far as our analyses enable us to discern). It remains a difficult issue is to judge the impact of the repertoire of participation associated with cosmopolitan areas.

Political elites are aware that politics is changing. The institutional solutions so far trialled by political elites are based on engaging with citizens in new and different ways but tokenistic power-sharing is likely to have limited impact. Political parties are offering multi-speed memberships stretching beyond the traditional full form to trial periods, through supporter or funder roles to various types of online engagement. ${ }^{\text {xxi }}$ Governments at local, regional, national and supranational levels are experimenting with democratic innovations and new forms of political participation. ${ }^{\text {xxi }}$ One issue is that most of these practices are tacked on to existing sets of political institutions, formulas and standard operating procedures that have not substantially changed. They provide window-dressing to a political practice that remains fundamentally the same. Another issue is that the media often appear happy to play the role of defender of the traditional in politics and are sceptical about any new practices, making the task for would-be reformers all the more challenging. The scale of the social, economic and cultural changes outlined in our analysis suggests that more fundamental shifts in political practice by mainstream actors will be required.

\section{Conclusion}

England is developing a bifurcated political world. Cosmopolitan citizens tend to be more socially liberal, open to change, and more positive about the impact of immigration and global demands. Citizens in backwater areas are more socially conservative and fear change, immigration and global dynamics. Weaker but still relevant differences in political repertoires 
and styles also exist, with cosmopolitan citizens more inclined to engage and use online or more informal methods compared to the residents of backwater locations. There may be varieties of provincial backwaters too, reflecting distinct economic and demographic trajectories - such as the economic decline of former northern industrial towns with migrant communities. Citizens are poles apart in these two types of area in terms of their attitudes to the economic and social landscape. Both groups represent potentially powerful if substantially contradictory challenges to mainstream politics. Heightening the challenge is the fact that both groups have little trust in mainstream politics.

Beyond England, the dynamics of this cosmopolitan versus backwater fission will vary depending on the economic location, institutional inheritance and cultural characteristics of different countries and regions. It will be tempered by the large number of citizens that are not at the polar edges of the attitudinal cosmopolitan/backwater political divide we identify. But it is far from clear that national political elites and actors will be able to rise to the challenge of this new economic and political context. The public disdain for their actions from both sides of the geo-economic divide limits their scope for action. The new fracturing of politics is setting an agenda and a dynamic of political participation that creates intractable dilemmas for national leaders. Local actors may be able more easily to offer both a political and a policy response that fits with their context but even they face a considerable challenge in meeting the diverse needs of cosmopolitan and backwater locations. 


\section{SUPPLEMENTARY MATERIALS}

\section{Table S1: Mosaic Types in Cosmopolitan and Backwater Parliamentary Constituencies}

\section{Mosaic ID Descriptor}

\section{Cosmopolitan}

$\mathrm{C} 10$

$\mathrm{C} 11$

C12

E17

F22

G26

G27

G28

G29

G30

G31

G32

G34

H36

\section{Backwater}

B6

B7

B8

$\mathrm{J} 45$

K51

L53

L54

M56

M58

N61
Wealthy families in substantial houses with little community involvement

Creative professionals seeking involvement in local communities

Residents in smart city centre flats who make little use of public services

Comfortably off suburban families weakly tied to their local community

Busy executives in town houses in dormitory settlements

Well educated singles living in purpose built flats

City dwellers owning houses in older neighbourhoods

Singles and sharers occupying converted Victorian houses

Young professional families settling in better quality older terraces

Diverse communities of well-educated singles living in smart, small flats

Owners in smart purpose built flats in prestige locations, many newly built

Students and other transient singles in multi-let houses

Students involved in college and university communities

Young singles and sharers renting small purpose built flats

Self-employed trades people living in smaller communities

Empty nester owner occupiers making little use of public services

Mixed communities with many single people in the centres of small towns

Low income communities reliant on low skill industrial jobs

Often indebted families living in low rise estates

Residents in retirement, second home and tourist communities

Retired people of modest means commonly living in seaside bungalows

Older people living on social housing estates with limited budgets

Less mobile older people requiring a degree of care

Childless tenants in social housing flats with modest social needs 


\section{Table S2: list of constituencies sampled from the cosmopolitan/backwater profiles}

\begin{tabular}{|c|c|c|}
\hline Rank & Constituencies - Clactons & Constituencies - Cambridges \\
\hline 1 & Clacton & Cities of London and Westminster \\
\hline 2 & Norfolk North & Chelsea and Fulham \\
\hline 3 & Isle of Wight & Wimbledon \\
\hline 4 & Totnes & Kensington \\
\hline 5 & Louth and Horncastle & Richmond Park \\
\hline 6 & St Austell and Newquay & Ealing Central and Acton \\
\hline 7 & Norfolk North West & Twickenham \\
\hline 8 & Suffolk Coastal & Hampstead and Kilburn \\
\hline 9 & New Forest West & Finchley and Golders Green \\
\hline 10 & Norfolk South West & Putney \\
\hline 11 & St Ives & Battersea \\
\hline 12 & Bexhill and Battle & Westminster North \\
\hline 13 & Dorset West & Hammersmith \\
\hline 14 & Thanet North & Enfield Southgate \\
\hline 15 & Tiverton and Honiton & Bristol West \\
\hline 16 & Christchurch & Kingston and Surbiton \\
\hline 17 & Cambridgeshire North East & Brentford and Isleworth \\
\hline 18 & South Holland and The Deepings & Tooting \\
\hline 19 & Camborne and Redruth & Chipping Barnet \\
\hline 20 & Norfolk Mid & Sutton and Cheam \\
\hline 21 & Cornwall South East & Brighton Pavilion \\
\hline 22 & Broadland & Manchester Withington \\
\hline 23 & Great Yarmouth & Hornsey and Wood Green \\
\hline 24 & Bognor Regis and Littlehampton & Holborn and St Pancras \\
\hline 25 & Cornwall North & Beckenham \\
\hline 26 & Bridgwater and Somerset West & Islington South and Finsbury \\
\hline 27 & Boston and Skegness & Harrow West \\
\hline 28 & Devon East & Cambridge \\
\hline 29 & Waveney & Hove \\
\hline 30 & Yorkshire East & Poplar and Limehouse \\
\hline 31 & Lewes & Reading East \\
\hline 32 & Devon North & Sheffield Central \\
\hline 33 & Devon West and Torridge & Dulwich and West Norwood \\
\hline 34 & Dorset South & Watford \\
\hline 35 & Norfolk South & Islington North \\
\hline 36 & Newton Abbot & Hendon \\
\hline 37 & Folkestone and Hythe & St Albans \\
\hline 38 & Dover & Bermondsey and Old Southwark \\
\hline 39 & Thanet South & Brent North \\
\hline 40 & Havant & Bath \\
\hline 41 & Harwich and Essex North & Esher and Walton \\
\hline 42 & Suffolk South & Lewisham West and Penge \\
\hline 43 & Eastbourne & Streatham \\
\hline 44 & Yeovil & Chingford and Woodford Green \\
\hline 45 & Brigg and Goole & Bromley and Chislehurst \\
\hline 46 & Berwick-upon-Tweed & Guildford \\
\hline 47 & Scarborough and Whitby & Carshalton and Wallington \\
\hline 48 & Wells & Ilford North \\
\hline 49 & Hastings and Rye & Harrow East \\
\hline 50 & Sleaford and North Hykeham & Vauxhall \\
\hline
\end{tabular}

Note: Welsh and Scottish constituencies excluded from the sampling exercise. 


\section{Notes}

i J. Cliffe, Britain's cosmopolitan future, London, Policy Network, 2015.
ii C. Martinez-Fernandez, I. Audirac, S. Fol and E. Cunningham-Sabot, 'Shrinking Cities: Urban Challenges of
Globalization', International Journal of Urban and Regional Research, vol. 36, 2012, pp.213-214.

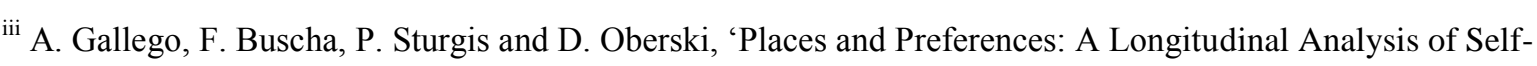
Selection and Contextual Effects', British Journal of Political Science, Early View, 2014. doi: $10.1017 / \mathrm{S} 0007123414000337$.

${ }^{\text {iv }}$ Backwaters are experiencing much lower rates of population growth in relative terms. Mid-year population estimates from the Office for National Statistics show that the populations of backwater constituencies grew by $5.8 \%$ between 2002 and 2011, compared to a rate of $10.5 \%$ in cosmopolitan areas.

${ }^{\mathrm{v}} \mathrm{T}$-tests of differences in means confirm that social attitudes in the two sets of constituencies are statistically different, at the 95 per cent level, both from each other and from the mean for all English constituencies, with the exception of attitudes on gender equality where there is no difference.

${ }^{\mathrm{vi}}$ For expression of English identity, above or at least equal to Britishness, a t-test finds weaker support for the difference in means of shrinking constituencies compared to all English constituencies, but the divide between cosmopolitan and shrinking areas remains significant (the differences are weaker still for the specific points on the Moreno-scale of national identity).

vii $\mathrm{T}$-tests of differences in means confirm these findings, with levels of participation being statistically different in shrinking and cosmopolitan constituencies for particular activities (having worked for a political party or action group, having donated to a party, organization or cause, having been on a demonstration and having boycotted products), but with few significant differences between shrinking areas and all English constituencies.

viii See, e.g. Hansard Society, Audit of Political Engagement 11, London, Hansard Society, 2014.

ix $\mathrm{T}$-tests of the difference in means again confirm that these differences are statistically significant, and also that shrinking and cosmopolitan areas also differ from the average English constituency.

${ }^{\mathrm{x}}$ R. Ford and M. Goodwin, Revolt on the Right, London, Routledge, 2014.

${ }^{x i}$ R. Syal, 'Disproportionate number of Labour's new members are wealthy city dwellers.' The Guardian, 21 January 2016.

${ }^{x i i}$ For a sense of what is going on see the Cities and Local Government Devolution Bill, 2015/16 and the AllParty Parliamentary Group on Reform, Decentralisation and Devolution Inquiry into Better Devolution for all $U K$. In addition there is some very helpful material from Mark Sandford at the House of Commons Library on the various devolution deals

http://researchbriefings.parliament.uk/ResearchBriefing/Summary/SN07029\#fullreport and the new local government finance arrangements http://commonslibraryblog.com/2016/01/07/equalisation-inches-back-intothe-local-government-finance-system/

${ }^{x i i i}$ C. Chwalisz, The Populist Signal, London: Policy Network, 2015, p.9.

${ }^{\text {xiv }}$ T. Akkerman and M. Rooduijn, 'Pariahs or Partners? Inclusion and Exclusion of Radical Right Parties and the Effects on Their Policy Positions', Political Studies, Early View, 2014.

${ }^{x v}$ M. McCombs and J-H. Zhu, 'Capacity, Diversity and Volatility of the Public Agenda: Trends from 1954 to 1994’, Public Opinion Quarterly, vol. 59, 1995, pp.495-525.

${ }^{\mathrm{xvi}} \mathrm{P}$. Webb, 'Who is willing to participate? Dissatisfied democrats, stealth democrats and populists in the United Kingdom’ European Journal of Political Research, vol. 52, 2013, pp.747-772.

${ }^{x v i i}$ G. Stoker and C. Hay, 'Understanding and Challenging Populist Negativity towards Politics: The Perspectives of British Citizens', Political Studies, forthcoming, 2016

${ }^{\text {xiii }}$ Ford and Goodwin, Revolt on the Right.

${ }^{x i x}$ On this point see C. Mudde https://www.opendemocracy.net/can-europe-make-it/cas-mudde/populism-ineurope-primer

${ }^{x x}$ J. Ekman and E. Amna, 'Political participation and Civic Engagement: Towards a New Typology', Human Affairs, vol. 22, 2012, pp.283-300. 
${ }^{x x i}$ S. Scarrow, 'Beyond Party Membership: Expanding Views of Partisan Participation', Paper prepared for "Towards More Multifaceted Understandings of Party Membership" Conference held at CVAP (Center for Elections and Parties), Copenhagen University, June 6-7, 2013.

xxii G. Smith, Democratic Innovations, Cambridge: Cambridge University Press, 2009; see also evidence of new practices collected at http://www.participedia.net/. 